\author{
Brusylovska Olga \\ Prof., Dr. (Political Sciences) \\ Department of International Relations \\ Odesa I. I. Mechnikov National University, \\ French Blvd., 24/26, Odesa, Ukraine \\ Tel.: +30482633259 \\ E-mail: brusylovska@onu.edu.ua \\ ORCID iD: https://orcid.org/0000-0003-0519-4206 \\ DOI: http://dx.doi.org/10.18524/2707-5206.2021.34.237502

\section{Khakimova Valeria} \\ PhD student \\ Department of International Relations, \\ Odesa I. I. Mechnikov National University \\ French Blvd., 24/26, Odesa, Ukraine \\ Tel.: +30482633259 \\ E-mail: valeriya080797@gmail.com \\ ORCID iD: https://orcid.org/0000-0001-6281-2715 \\ DOI: http://dx.doi.org/10.18524/2707-5206.2021.34.237502
}

\title{
PECULIARITIES OF THE EU'S SOFT POWER STRATEGY TOWARDS UKRAINE
}

Proclaiming a new world order, the leaders of Western states provided for the expansion of peace and stability by assisting with Europeanization and the integration of Central and Eastern Europe. However, the situation with Ukraine is more complicated. The aim of the paper is revealing of the EU's soft power peculiarities towards Ukraine. The methodology is based on studies of Joseph Nye and the USC Centre of Public Diplomacy. Both have been adapted and implemented to the aims of the current study. The most important questions are: What makes the EU attractive abroad? To what extent does the EU rely on its attractiveness in its relations with Ukraine? What prevents the EU from more effectively pursuing its soft power policy towards Ukraine? As a result of this work, it became clear that the EU's influence on Ukraine and in particular on the solution of the current conflict with Russia was insignificant. This is a paradox if we consider the individual characteristics of both actors. The EU still loses to Russia in digital diplomacy. However, in terms of the attractiveness of cultural achievements, the strength of the EU is about the same as that of Russia. The strength of the diplomatic network, its contribution to global interaction in the case of the EU is relatively higher than that of Russia. Finally, the EU's strength is much higher than that of Russia in terms of the attractive economic model, business friendliness, and ability to innovate; by the level of human capital, contribution to scholarships, and attractiveness for international students; in the context of a commitment to freedom, human rights and democracy, and the quality of political institutions. In the future, it is necessary to conduct a study of this phenomenon and find out what affects the EU's inability to use its soft power advantages effectively.

Key words: the European Union, Ukraine, soft power, digital diplomacy, grand strategy, Association Agreement. 


\section{Introduction}

The European Union (EU) is one of the most unusual actors in world politics because it uses mostly soft power instruments to defence its values abroad. Joseph S. Nye, Jr. has been the key protagonist of the soft power concept over the past two decades. Nye has defined soft power as "the ability to shape the preferences of others" (Nye, 2004). The key aspect of soft power is the attractiveness of a country. Despite numerous criticisms of Nye's concept, even realists such as Carr and Morgenthau have admitted that power was not only military and economic. In order to influence the behavior of others, the important elements of power are involvement, influence on public opinion in other countries, the opportunity to be accepted as a figure with authority, to form social categories of subjects of world politics.

The Digital Diplomacy Hub of USC Centre on Public Diplomacy in Portland has developed an original model for studying the soft power of states which is useful to consider when studying the strength of the EU.

Table 1

\section{Methodology of the Digital Diplomacy Hub}

\begin{tabular}{|l|l|}
\hline Digital & $\begin{array}{l}\text { A country's digital infrastructure and its capabilities in digital diplo- } \\
\text { macy }\end{array}$ \\
\hline Culture & $\begin{array}{l}\text { The global reach and appeal of a nation's cultural outputs, both } \\
\text { pop-culture and high-culture }\end{array}$ \\
\hline Enterprise & $\begin{array}{l}\text { The attractiveness of a country's economic model, business friendli- } \\
\text { ness, and capacity for innovation }\end{array}$ \\
\hline Education & $\begin{array}{l}\text { The level of human capital in a country, contribution to scholarship, } \\
\text { and attractiveness to international students }\end{array}$ \\
\hline Engagement & $\begin{array}{l}\text { The strength of a country's diplomatic network and its contribution } \\
\text { to global engagement and development }\end{array}$ \\
\hline Government & $\begin{array}{l}\text { Commitment to freedom, human rights, and democracy, and the qual- } \\
\text { ity of political institutions }\end{array}$ \\
\hline
\end{tabular}

Source (What is soft power, 2019)

Therefore the aim of the paper is revealing of the EU's soft power peculiarities towards Ukraine. The methods has been adapted and implemented by us in accordance with the aims the study related to Ukrainian case. Preliminary research includes the results about the soft power of Russia (Brusylovska, 2018) but the current study enlarges the field including the new subject (the EU) and the period (until 2020).

The collected and selected materials are concepts, strategic documents, reports, political and associate agreements, official political statements and state addresses, pre-election programs and elections' results, media publications, and broadcasts, experts' analyses, empirical research, etc. The materials form the period of 8 years (2013-2020) and allow a study of the soft power at the supra-national level (the EU).

The research is organized following strictly six steps of research design (digital power, cultural power, enterprise power, education power, engagement power, government power). 


\section{Digital Power of the EU}

The essence of the EU digital diplomacy is to form a positive media space on the regional development of the European community and foreign policy initiatives of the Union using online tools. In particular, more than 216 accounts open on various social media platforms (Facebook, MySpace, Hyves, LinkedIn, Twitter, Blip, Flickr, Picasa, Daily Motion, YouTube, and Vimeo) for numerous EU institutions; allow European officials and European thematic projects to keep the first place in the world for reaching the audience. The European External Action Service, without replacing national foreign ministries, successfully complements the activity of diplomatic missions of the EU member states through effective communication with the world community using social media. About 142 official accounts of the EU delegations abroad have been created on social media; in addition to the globally popular profiles on Twitter, Facebook, and YouTube, thematic accounts have been opened on national social media (Sina Weibo, Tencent Weibo, Flickr, or Storify). For the correct Web presence of the European Commission, the Europa Web Guide, 12 which defines the official editorial, legal, technical, visual, and contractual rules, has been created. Within the European Union, digital diplomacy instruments are used for supporting the EU's political priorities, developing a common position on international events, promoting economic attractiveness of the European region, or personal and professional communicating (Pipchenko, 2020, p. 24).

Ukraine takes an example from Europe and the Ministry of Foreign Affairs of Ukraine actively uses social networks as an important diplomatic tool, with their help informs the foreign audience about Ukraine and its foreign policy. Since 2014, as a result of the aggravation of Ukrainian-Russian relations, the Ministry of Foreign Affairs revised the instruments for supporting Ukraine's foreign policy interests and initiatives, as well as intensified the work of Ukrainian diplomatic missions. According to European experts, Russian propaganda has proven to be extremely flexible, which is why it can target everyone. The Kremlin's disinformation operations are only part of a broader offensive using so-called "soft power" aimed at subversive activities against other countries for its own political gain and to restore Russia's status as a great power (Hellman \& Wagnsson, 2017, p. 155). Russian Defence Minister Sergei Shoigu acknowledged in 2017 that special information warfare forces had been set up at the Ministry of Defence in 2013 (N. Bentzen, 2017). Misinformation is part of Russia's official military doctrine and is a universally recognized instrument of its foreign policy. And although Russia's disinformation policy has been going on for decades, the EU only took action in 2015 by setting up the East StratCom (ESTF) working group.

Generally, the functioning of the EU digital policy in the region has been strengthened by the work of the new EU East StratCom Task Force (ESTF). The Action Plan on Strategic Communication, presented in June 2015, has three main objectives: Effective communication and promotion of EU policies towards the Eastern Neighbourhood; Strengthening the overall media environment in the Eastern Neighbourhood and EU Member States, including 
support for media freedom and strengthening independent media; Improving EU capacity to forecast, address and respond to disinformation activities by external actors. The goal of countering Russian influence is to contain the threat by developing a sustainable soft power dialogue between values and ideals (Bjola \& Pamment, 2016, p. 133). According to the website of the ESTF, its task is to actively explain key aspects of EU policy, to create a positive image of the EU and countering disinformation. The East StratCom Task Force is responsible for collecting and disseminating all identified examples of Russian disinformation attacks on the EUvsDisinfo.eu website, and is responsible for editing the official Russian-language website of the EU's European External Action Service (Questions and Answers about the East StratCom Task Force, 2018). The leading institutions whose occupation is connected to the fight against disinformation (primarily online) are the European Commission (it has established, in particular, the High Level Expert Group, HLEG; Media Expert Group on Media Literacy); European Parliament (in particular, the political-administrative body The Panel for the Future of Science and Technology (STOA), European Ideas Network); Operational Working Group on Strategic Communications (East StratCom Task Force) as part of the European External Action Service; Council of the European Union; European Union Agency for Network and Information Security (ENISA), EU Intelligence and Situation Centre (INTCEN) (Dubov, 2020, p. 53). While the EU is making some progress in digitalizing its diplomacy, it is worth noting that the time of the opposition to Russia in the digital sphere was missed.

\section{Culture Power of the EU}

The EU has progressively tried to develop its own approach starting from the 2007 European agenda for culture in a globalizing world, which identified 'culture in external relations' as one of its pillars. Successive Council Conclusions, European Parliament (EP) resolutions and an ad-hoc Preparatory Action led to the 2016 Joint Communication Towards an EU strategy for international cultural relations (hereafter 2016 Communication) presented by the European Commission (EC) in June 2016, later endorsed by the Council and European Parliament (EP). International cultural relations (ICR) were also incorporated in broader EU cultural policies, becoming one of the three objectives on the 2018 New European Agenda for Culture and one of the five priorities of the Work Plan for Culture 2019-2022 adopted by the Council (Trobbiani \& Pavyn-Guinea, 2019, p. 3).

Building economic, social and human development as well as trust and peaceful relations with third countries starting from the European Neighbourhood are EU's key priorities, all aims to which international cultural relations can potentially contribute, depending on the size and quality of resources invested.

The Creative Europe is a $€ 1.46$ billion EU's programme for the cultural and creative sectors for the years 2014-2020. The programme was approved and adopted by the European Council in 2014. The general objectives of Creative Europe are: (a) to preserve, develop and promote European cultural and lin- 
guistic diversity and to promote Europe's cultural heritage; (b) to strengthen the competitiveness of the European cultural and creative sectors, in particular of the audio-visual sector, with a view to promoting smart, sustainable and inclusive growth. Creative Europe encompasses the EU's previous Culture and MEDIA Programmes which have been in effect for more than 20 years. These strands now serve as sub-programmes under Creative Europe, with the Culture sub-programme supporting performing and visual arts, heritage and other areas, and the MEDIA sub-programme providing funding for the cinema and audio-visual sector. In addition, there is a new cross-sectorial strand supporting policy cooperation, transversal measures and a new financial guarantee facility, which will be operational from 2016. Programmes that existed under the Culture and MEDIA strands, such as the European Capitals of Culture, European Heritage Label, European Heritage Days and the five European prizes (EU Prize for Cultural Heritage/Europa Nostra Awards, EU Prize for Contemporary Architecture, EU Prize for Literature, European Border Breakers Awards, and EU Prix MEDIA) continue to operate under Creative Europe. Also the project Re-Imagine Europe, which was initiated by Sonic Acts, is co-funded by Creative Europe (Про програму “Креативна Європа”, 2018).

Ukraine has joined and actively participated in Creative Europe since 2016, with the support of this program in Ukraine were conducted about 40 successful projects. Involvement in European cultural processes is very important for Ukraine. That is why the Ministry of Culture and Information Policy fully supports the participation of our country in European programs and initiatives in the cultural sector, promotes networking between professionals and encourages creative exchanges and other forms of cooperation between artists in the cultural and creative industries.

\section{Enterprise Power of the EU}

There are serious economic reasons allowing speaking on global leadership of the European Union. Such international statistical indicators as territory area, population size, annual GDP, economic growth rates, share in world trade etc. Since its inception, the EU has also become the largest trading bloc and aid provider in the world, adding further weight to its international role. The soft power of the European Union is implemented in the programs to reformation of economies of neighbouring countries. In an effort to ease the solution of their social and economic problems, the European Union is simultaneously orienting them towards European economic and trade priorities.

In 2014, EU funding through the European Neighbourhood Instrument (ENI) amounted to $€ 365$ million, the highest amount ever committed for bilateral aid to Ukraine. This responded to the urgent need to stabilize Ukraine's economy, with a major State Building Contract, to address short-term economic problems and to prepare for in-depth reform in the context of political association and economic integration with the EU. The country also received $€ 1.360$ billion in macro-financial assistance loans in 2014, and should receive an additional $€ 250$ million in April 2015, should the IMF programme remain on track and the policy conditions be met. All measures combined could bring 
overall support of at least $€ 11$ billion over $2015-2016$ from the EU budget and EU based international financial institutions (Відносини між $\mathrm{EC}$ та Україною, 2018).

The AA and DCFTA entered into force on September 1, 2017. The agreement launches the reform of the legislative framework of Ukraine aimed at bringing the legislation in line with the EU legal acts. Ukrainian enterprises receive stable and predictable privileged access to a single market in the world with more than 500 million consumers. And EU companies can benefit from easy access to the Ukrainian market and to establish new ones relations with suppliers and partners. In 2017, the volume of exports from Ukraine to the EU increased by $27 \%$, with estimates for 2018 indicating growth trend (Відносини між ЄС та Україною, 2018).

In September 2018, the European Commission signed with Ukraine Memorandum of Understanding on providing macro-financial assistance in the amount of up to 1 billion Euros medium and long-term loans. With this help the EU will continue to support economic stabilization in the country, in this including through structural and managerial reforms. Private Sector Development Program ( $€ 110$ million) - assistance in restoring the Ukrainian economy through the provision of technical assistance to improve the legal framework for SMEs, support to creation of centres of business consulting in the regions which facilitate access to finance. The EU assisted the Ukrainian government in establishing an independent regulatory body on energy issues, as well as the development of new legislation in gas and electricity industries to improve efficiency the energy sector. In close cooperation with partners and financial institutions, such as the European Investment Bank, the EBRD, and the World Bank, the European Union continues to support the modernization of Ukraine's gas transportation system by providing reconstruction of parts of the East-West transit pipelines. Aligning energy legislation and practice with the "Third Energy Package" are recommended to Ukraine. The EU has supported the implementation of an ambitious agenda for transport development, which greatly contributes to the implementation of the AA/ DCFTA. The development of transport and transport connections is the basis for strengthening the movement and circulation of people and goods between Ukraine and the EU and will contribute to the growth of trade and the economy. The EU remains the largest trading partner a partner of Ukraine - its share in the foreign trade of the country is over $42 \%$. Reforms enshrined in the AA and DCFTA will contribute to the improvement of the overall business climate in Ukraine, including the fight against corruption and elimination protectionist measures, which in turn will increase the level of trust investors. The EU has supported the state authorities of Ukraine in creation of an independent regulatory body on electronic matters communications, as well as in strengthening Ukraine's resilience to threats cyber security (Відносини між $\mathrm{CC}$ та Україною, 2018). Exports to the EU compensated for the decline of Ukrainian trade with the Russian Federation.

So, DCFTA is an important part of Association Agreement. The idea DCFTA can have mixed results. Those aspects what for the neighbours of the 
European Union should be an important stimulus is a form of cooperation that conceals serious risks at least in the short and medium term. DCFTA mean for the economies of neighbouring states of the European Union a significant cost to adapt its market to EU requirements.

\section{Education Power of the EU}

Frequently there is emphasis on the importance of rising cooperation on youth, student, researcher and professor exchanges and the development of scholarship programmes which will enable the Eastern countries citizens to learn about and to share European values (Costea, 2012, p. 54). The EU extends some programmes and financing (especially in the fields of education, research and culture) to those Eastern countries that prove they share European and democratic aspirations, through real reform policies, and Ukraine is no exception.

Horizon 2020 is the largest EU research and innovation program ever, with nearly $€ 80$ billion in funding available over 7 years (2014 to 2020) - in addition to the private investment that this money will attract. It promises more breakthroughs, discoveries and advances in the world by bringing great ideas from laboratory to market. Horizon 2020 is a financial instrument that implements the Innovation Union, a Europe 2020 flagship initiative aimed at making Europe globally competitive. Seen as a vehicle for spurring economic growth and job creation, Horizon 2020 enjoys political support from European leaders and members of the European Parliament. They agreed that research is an investment in Europe's future and therefore put it at the heart of the EU's agenda for smart, sustainable and inclusive growth and job creation. By bounding research and innovation, Horizon 2020 helps achieve this with an emphasis on excellence in science, industry leadership and social problem solving. The goal is to ensure that Europe produces world-class science, removes barriers to innovation and makes it easier for the public and private sectors to work together to deliver innovation (Проекти НІП України, 2018).

Horizon 2020 has been replaced by a new international research and innovation framework - "Horizon Europe", which is the largest of its kind in the world. Suffice it to say that its total budget is 95.5 billion euros. This is $30 \%$ more than was allocated for the previous program. In addition, the program provides new mechanisms and decision-making tools compared to previous EU research framework programs. These include the European Council for Innovation, research missions, partnerships to improve the research environment, and more. It covers the period from 2021 to 2027, and its main goal is to solve global problems and promote industrial modernization through coordinated research and innovation. Five main directions of its implementation are clear from the goal. These are "Adapting to Climate Change", "Including Social Transformation", "Fighting Cancer", "Climate Neutral and Smart Cities", "Healthy Oceans, Seas, Coastal and Inland Waters, and Soil Health and Nutrition". The opportunities offered by the new European Union program for researchers and the countries in which they work are very interesting for Ukraine as well. Because the program "Horizon Europe" provides for the prin- 
ciple of open competitions which are announced by the European Commission (The EU "Horizon Europe" program has started, 2021).

Moreover, Ukraine is one of the largest beneficiaries of the Erasmus+ program Eastern Partnership Region. More than 7,000 Ukrainian students and representatives of the academic staff took advantage of the program's capabilities Erasmus+ exchanges (Відносини між $6 C$ та Україною, 2018).

\section{Engagement Power of the EU}

After Euromaidan the EU was waiting for the election of a new president in Ukraine, but after the election of Petro Poroshenko, the statement of EU leaders did not change in general tone: support for Ukraine, calls for cooperation at all levels and among all parties, resolving the crisis peacefully, execution of Geneva agreements, the introduction of sanctions against Russia. However, a proposal to give Ukraine, Moldova, and Georgia, with the prospect of full membership in the EU as an alternative to Russian EEC project was presented for the first time. It was announced by Stefan Füle, European Commissioner for Enlargement, in an interview with German newspaper Die Welt on May 30, 2014: "If we seriously seek for transformation in Eastern Europe, then we have to use the most powerful instrument that contributes conversion - extension". He expressed the same considerations that Ukraine has been trying to convey to Brussels for a long time: European perspective, despite the existence of a number of preconditions, was the best incentive for real reforms.

In 2013 the EU recommended several new actions to Ukraine: decentralization reforms; harmonization of all electoral legislation; judicial reform in line with European standards and in close consultation with the Council of Europe/Venice Commission; the lustration; anti-corruption legal package; reform of the public administration, police reform; and continuing to investigate independently the violent acts which occurred during civil protests between November 2013 and February 2014, as well as the tragic events in Odesa in May 2014, with the support of the International Advisory Panel proposed by the Council of Europe (ENP Country Progress, 2015).

Part of the funding ( $€ 40$ million) for Ukraine was granted from the ENI umbrella programme, the incentive-based mechanism that rewards progress in building deep and sustainable democracy. It also comprises a dedicated support to civil society organizations to help them voice their concerns and effectively monitor national reforms. Unfolding events made it difficult to pre-identify the focus of EU assistance to Ukraine over several years; this is why, for the time being, EU assistance is committed in the form of annual special measures. In addition to ENI, Ukraine also benefitted from other EU support, including humanitarian assistance for up to $€ 139$ million and the thematic programme for Civil Society and Local Authorities ( $€ 2$ million). The EU supports a program for the development of civil society with a budget of $€ 20$ million, which aims to increase the capacity of civil society to support and monitor implementation of the launched reform program (Відносини між ЄC та Україною, 2018). The EU set up the EU Advisory Mission for Civilian 
Security Reform (EUAM Ukraine) to assist the country in reforming its civilian security sector, including the rule of law and the police.

Civil society has been developing quickly in Ukraine. The process of decentralizing competences was launched, notably on the amalgamation of municipalities and on budget decentralization. A nationwide decentralization program ( $€ 90$ million) providing advice and support on improving the transparency and accountability of local and regional authorities, and as well as the strengthening of local administrative centres. 27 administrative centres were open in all areas of Ukraine. Program for reforming public administration (104 million Euros) is aimed at the formation of a new generation government officials, the reorganization of government structures for the purpose ensuring compliance with EU standards, as well as developing the best practices in shaping policies and promoting key sectorial reforms. Anti-corruption program (15 million Euros) supports for newly created anti-corruption institutions, strengthening parliamentary control, as well as capacity building civil society and independent media for assistance fight against corruption (Відносини між ЄС та Україною, 2018).

At the same time K. Wolczuk and T. Kuzio pointed out that the benefits of the ENP would not stimulate a far-reaching reform (Maksymenko \& Kuzmin, 2017). Firstly, in order to mobilize domestic support for reforms (first of all, to overcome internal barriers to reform, social ambivalence, and to reach consensus among political elites), for Ukraine, 'Europe' should become, first and foremost, a political, and not only economic project. Secondly, the cost-benefit ratio for Ukraine is less attractive than for the countries with the prospect of membership. Especially considering that the political and economic transformation of Ukraine was equal to the preparation for membership, and the requirements set out in the ENP coincided with similar requirements for associated members. Thirdly, the ENP and its undifferentiated approach do not provide the EU with sufficient leverage on the countries. This situation only strengthened asymmetric relations between the EU and applicant states, putting pressure on the domestic situations in the latter, causing a sense of double standards in the EU's 'open door' policy.

Unfortunately, the EU failed to adequately assess the significance of the events of the Euromaidan in Ukraine and Russia's readiness to take extraordinary steps. Moreover, Euromaidan has accumulated contradictions in the system of relations between the EU and Russia. These protests challenged European "Russian policy" and the logic of European development. It is obvious, for example, that the policy of the Eastern Partnership does not satisfy the aspirations for integration into the European legal, political and economic space that Ukraine offers. Statements of representatives and EU institutions in support of the "right of sovereign states to conduct foreign policy without external pressure" (European Parliament, 2013), calling for a "democratic solution of the political crisis in Ukraine" did not correspond to either the current situation or the "value-oriented" policy of the EU in the region.

But generally after beginning of the war between Ukraine and Russia, the EU intensified its cooperation with Ukraine. Ukraine signed the political 
provisions of the Association Agreement (AA) on 21 March 2014 and the provisions of the remaining parts on 27 June 2014. On 16 September 2014, the Association Agreement was ratified by the Ukrainian Parliament and consent was given by the European Parliament, enabling the provisional application of the relevant provisions of the Association Agreement as of 1 November 2014 and the DCFTA-part as of 1 January 2016. Ukraine also adopted a number of important legislative reforms to address the benchmarks of the Visa Liberalization Action Plan (ENP Country Progress, 2015).

\section{Government Power of the EU}

The European Union is one of the largest and influential players in the field of world politics. It carries out its political activities in the framework of the mechanism of the Common Foreign Policy and Security Policy, incorporated into the structure of the working bodies of the European Union. European Union's policy towards its neighbours is carried out on the basis of a common goal - the establishment of EU zone of stability and prosperity, consisting of friendly countries.

There were a lot of expectations from the Ukrainian people's side that the AA between Ukraine and the EU would be an impetus and a particular algorithm for developing a new form of social-political relations. But for the EU the situation was not so simple. The largest fear of the member states will come true - war will come back to Europe. But if Poland, Sweden, and the Baltic countries are ready for more decisive action, those EU Member States economically associated with Russia (Greece, Italy, Cyprus, Hungary, and Czech Republic) and even France and Germany stand for normalizing relations with Russia. This is the key to the relationship between Ukraine and the EU.

The outcome of the 17th Ukraine-EU Summit and the Riga Eastern Partnership Summit indicate that the EU is not eager to offer anything more than the existing format of relations. On one hand, the EU expects Ukraine's progress in the implementation of the provisions of the $\mathrm{AA}$, and, on the other hand, it hopes to reach a compromise with Russia. A similar position of the EU is threatening for Ukraine. On the other hand, as the results of the "the Normandy Contact Group" showed, France and Germany put pressure on Ukraine on the issue of the implementation of the Minsk agreements, having no effective mechanism to force Russia to fulfil its obligations. As Alain Guilmeau, a French writer, rightly noted, "the interests of Europeans and Ukrainians within this format do not necessarily coincide, but the resolution of the crisis in Ukraine" is a chance for the EU to achieve great success (BBC, 2016). The EU does not want to hear the arguments of Ukraine: the withdrawal of Russian troops is not possible without ceasefire, fair elections on the occupied territories of Donbas, and consolidating the special status of these territories in the Constitution legalizes the occupation regime, which will conserve the problem for many years. Moreover, these elections will be a step to formalize the conflict in the East as purely internal, and Kyiv's refusal to negotiate formally with the legitimate representatives of the authorities on 
the occupied territories will eventually transform the Ukrainian authorities into those main responsible for the events and peace-making.

Thus, 2014, on one hand, has become a point of non-reciprocity in relations between Ukraine and the EU, has determined the activity, but also the ineffectiveness of relations that often became hostages of the domestic policy of the EU member states. So, migration and the Syrian crisis, terrorist attacks, Brexit, as well as the growth of right-wing populism and Euroscepticism within Europe have identified the negative attitude of $61-71 \%$ of residents of Austria, Germany, Luxembourg, France, Belgium, and Finland to further EU enlargement. However, 61-73\% of the population of Romania, Lithuania, Malta, and Croatia are "for". As for Ukraine, in 2014 its accession to the EU was supported by $52 \%$ of EU citizens (mostly from Poland, Sweden, Portugal, Spain, Greece, Italy) agreed that Ukraine should be given membership perspective (Litra \& Chxikvadze, 2016, p. 6). Referring to the words of Donald Tusk, the President of the European Council, who recognized that "the Ukrainian people deserve better" and "Ukraine's success will be the success of Europe" in November 2016, the conservation of practical integration of Ukraine into the European space will be failure for both sides.

\section{Generalization and conclusions}

When we talk about EU's attractiveness abroad we think first of all about its economic, political and cultural might. But today EU has exhausted its political potential for a deeper economic integration, stressing the necessity for the partner states to channel their efforts into the AA implementation and avoiding discussions on further integration prospects. For the most part of the post-Soviet period the multilateral format of the Eastern Partnership did not have meaningful prospects.

The EU relies on its attractiveness in its relations with Ukraine to some extent. The EU has the exclusive right to determine the prospect of membership of any state and the timing of its accession, and assessing the results of the implementation of bilateral agreements (PCA, Action Plans, and Association Agreement) is dependent on the Member States. But it intensifies the dilemma between political imperatives, practical interests and pressing tasks of the EU policy. To our mind, modern asymmetric relations between Kyiv and Brussels should be revised and the policy should be transparent. It is important for both sides. Without changes in this sphere attempts by the Ukrainian side to demonstrate its willingness to defend their own interests with regard to certain issues, including the prospect of Ukraine's membership in the EU or relations with Russia, has caused EU criticism and statements about Ukraine's failure to do its "homework". All this contributed to preserving the tendency to politicize the practical spheres of cooperation, denoting the "length" of the European route of Ukraine.

More effectively pursuing EU's soft power policy towards Ukraine depends on several factors. First of all, the geographic location of the region was determined by the strong influence of two major international actors - the EU and Russia, which has forced countries to either make geopolitical choices or 
implement a 'balancing policy'. In addition, the Eastern Partnership brings together countries with a different military-political orientation. Under conditions of incomprehensible advantages and prospects the member states are less interested in carrying out reforms and active participation in the implementation of the EaP program.

Summarizing we can say that the table 2 presented below includes theoretical and methodological contribution of the research adapting and implementing soft power theory, and in particular the Digital Diplomacy Hub model.

Table 2

Results of the Research of Soft Power Instruments of the EU: Case of Ukraine

\begin{tabular}{|l|l|}
\hline Digital & $\begin{array}{l}\text { A country's digital infrastructure and its capabilities in digital diplo- } \\
\text { macy - Russian is much higher than EU's. }\end{array}$ \\
\hline Culture & $\begin{array}{l}\text { The appeal of a nation's cultural outputs - EU's power is relatively } \\
\text { the same as Russian. }\end{array}$ \\
\hline Enterprise & $\begin{array}{l}\text { The attractiveness of a country's economic model, business friendli- } \\
\text { ness, and capacity for innovation - EU's power is much higher than } \\
\text { Russian. }\end{array}$ \\
\hline Education & $\begin{array}{l}\text { The level of human capital in a country, contribution to scholarship, } \\
\text { and attractiveness to international students - EU's power is much } \\
\text { higher than Russian. }\end{array}$ \\
\hline Engagement & $\begin{array}{l}\text { The strength of a country's diplomatic network and its contribution } \\
\text { to global engagement - EU's power is relatively higher than Russian. }\end{array}$ \\
\hline Government & $\begin{array}{l}\text { Commitment to freedom, human rights, and democracy, and the } \\
\text { quality of political institutions - EU's power is much higher than } \\
\text { Russian. }\end{array}$ \\
\hline
\end{tabular}

Source: own representation.

\section{References}

BBC. (2016, October 25), Chy ye majbutnye u "normandskoyi chetvirky"? (Does the "Norman Four" have a future?). Retrieved from https://www.bbc.com/ukrainian/politics/2016/10/161019 normandy_format_quartet_it). [in Ukrainian].

Bjola, C. \& Pamment, J. (2016). Digital containment: Revisiting containment strategy in the digital age. Global Affairs, 2, 133. Retrieved from https://www.researchgate.net/publication/303502281_Digital_containment_Revisiting_containment_strategy_in_the_digital_age. [in English].

Brusylovska, O. (2018). The Re-Politicisation of Modern Russian - Ukrainian Relations, Вісник Одеського національного університету. Соціологія та політичні науки. Політологія, 23, 2(31), 11-34. [in Ukrainian].

Costea, S. (2012). The European Union's Eastern Partnership: the Objective of Regional Cooperation, in The Eastern Partnership and the Europe 2020 strategy: Visions of leading policymakers and academics. (pp. 51-60). European Commission. Retrieved from http://bookshop.europa.eu/en/the-eastern-partnership-and-the-europe-2020-strategy-pbNC3211824/. [in English].

Creative Europe. (2018). Retrieved from https://https://eacea.ec.europa.eu/creative-europe_en. [in English].

Dubov, D. V. ta in. (2020). Feiky yak instrument vyplyvu na vybory (Fakes as a tool to Influence the Election). National Institute for Strategic Studies. Retrieved from https://niss.gov.ua/ sites/default/files/2020-01/fake_news_fin_full_clean.pdf [in Ukrainian].

European Parliament. (2014). European Neighbourhood Instrument, OJ L77, Article 2 of Regulation (EU) No 232/2014, 11 March, Brussels. [in English]. 
European Parliament. (2013). Resolution on the outcome of the Vilnius Summit and the future of the Eastern Partnership, in particular as regards Ukraine, 2983(RSP). Retrieved from http:// www.europarl.europa.eu/. [in English].

ENP Country Progress Report 2014 - Ukraine. (2015, March 25). Brussels. Retrieved from http://eeas.europa.eu/. [in English].

Hellman, M. \& Wagnsson, C. (2017). How can European states respond to Russian information warfare? An analytical framework. European Security, 26(2), 155.

Istrate, D. (2019), EaP Civil Society Forum publishes the latest Eastern Partnership Index. Retrieved from https://emerging-europe.com/. [in English].

Litra, L. \& Chxikvadze, I. (2016). Perspektyva chlenstva $v$ YeS dlya Gruziyi, Moldovy ta Ukrayiny: nemozhlyva, zabuta chy pryxovana? (The prospect of EU membership for Georgia, Moldova, and Ukraine: impossible, forgotten, or hidden? ). Kyiv: Institute of World Politics. [in Ukrainian].

Maksymenko, I. \& Kuzmin, D. (2017), Ukraine - European Union Relations through the Prism of Strategic Culture. In I. Koval, O. Brusylovska, V. Dubovyk (Eds.), Strategic Culture and Foreign Policy of Ukraine (pp. 54-75). Odesa: Odesa Mechnikov National University. [in English].

Nye, J. Jr. (2004), Soft Power: The Means to Success in World Politics. New York: Public Affairs. [in English].

Pipchenko, N. (2020). Digital diplomacy: how international actors transform their foreign policy activity. UA: Ukraine Analytica, 2(20). Retrieved from https://ukraine-analytica.org/wp-content/uploads/Pipchenko.pdf [in English].

Proekty NIP Ukrainy v Somii ramkovii prohrami YeS. (Ukraine's NIP projects in the EU's Seventh Framework Program). (2018). Retrieved from https://h2020.com.ua/uk). [in Ukrainian].

Pro prohramu "Kreatyvna Yevropa" (About the "Creative Europe" program). (2018). Retrieved from https://creativeeurope.in.ua/p/about). [in Ukrainian].

Questions and Answers about the East StratCom Task Force. (2018). Retrieved from https://eeas. europa.eu/headquarters/headquarters-homepage/2116/node/2116_en). [in English].

The EU "Horizon Europe" program has started. Researchers prepare...(2021). Kyiv Polytechnic, 5. Retrieved from https://kpi.ua/en/2021-kp5-icd. [in English].

Trobbiani, R. \& Pavyn-Guinea, A. (2019). Culture in EU External Relations: Strategic Reflections and Future Scenarios. Retrieved from https://cris.unu.edu/sites/cris.unu.edu/files/ELCSID \% 20Policy \% 20Paper \% 202019-16.pdf). [in English].

Vidnosyny mizh YeS ta Ukrayinoyu $u$ faktax ta cyfrax. (EU-Ukraine Relations in Facts and Figures). (2018). Retrieved from https://www.euneighbours.eu/uk/east/stay-informed/). [in Ukrainian].

What is Soft Power? (2019). USC Center on Public Diplomacy. Retrieved from https://softpower30.com/what-is-soft-power/). [in English].

\section{Список використаної літератури}

Відносини між ЄC та Україною у фактах та цифрах. 2018. URL: https://www.euneighbours. eu/uk/east/stay-informed/) (дата звернення 20.05.2021).

Дубов Д. В. та ін. Фейки як інструмент випливу на вибори. Київ: Національний інститут стратегічних досліджень, 2020. 209 с. URL: https://niss.gov.ua/sites/default/files/2020-01/ fake_news_fin_full_clean.pdf (дата звернення 15.05.2021).

Літра Л., Чхіквадзе І. Перспектива членства в ЄС для Грузії, Молдови та України: неможлива, забута чи прихована? Київ: Інститут світової політики, 2016. 19 с.

Чи є майбутне у «нормандської четвірки? ВВC. UA. 2016. 16 жовтня. URL: https://www. bbc.com/ukrainian/politics/2016/10/161019_normandy_format_quartet_it (дата звернення 11.05.2021).

Проекти НIП України в Сьомій рамковій програмі ЄC. 2018. URL: https://h2020.com.ua/uk (дата звернення 10.04.2021).

Про програму «Креативна Європа». 2018. URL: https://creativeeurope.in.ua/p/about) (дата звернення 17.05.2021).

Bjola C., Pamment J. Digital containment: Revisiting containment strategy in the digital age. Global Affairs. 2016. No. 2. 133 p. URL: https://www.researchgate.net/publication/303502281_ 
Digital_containment_Revisiting_containment_strategy_in_the_digital_age (дата звернення 15.05.2021).

Brusylovska O. The Re-Politicisation of Modern Russian - Ukrainian Relations. Вісник Одеського національного університету. Соціологія та політичні науки. Політологія. 2018. Вип. 23, т. 2(31). C. $11-34$.

Costea S. The European Union's Eastern Partnership: the Objective of Regional Cooperation, in The Eastern Partnership and the Europe 2020 Strategy: Visions of Leading Policymakers and Academics. European Commission. 2012. P. 51-60. URL: http://bookshop.europa.eu/ en/the-eastern-partnership-and-the-europe-2020-strategy-pbNC3211824/ (дата звернення 23.04.2021).

Creative Europe. 2018. URL: https://https://eacea.ec.europa.eu/creative-europe_en (дата звернення 27.04.2021).

European Parliament. European Neighbourhood Instrument, OJ L77, Article 2 of Regulation (EU). No 232/2014. Brussels, 2014. 11 March. P. 27-43.

European Parliament. Resolution on the outcome of the Vilnius Summit and the future of the Eastern Partnership, in particular as regards Ukraine, 2983(RSP). 2013. URL: http://www. europarl.europa.eu/ (дата звернення 25.04.2021).

ENP Country Progress Report 2014 - Ukraine. Brussels. 2015. 25 March. URL: http://eeas. europa.eu/) (дата звернення 27.04.2021).

Hellman M., Wagnsson C. How can European states respond to Russian information warfare? An analytical framework. European Security. 2017. Vol. 26, No. 2. P. 155.

Istrate D. EaP Civil Society Forum publishes latest Eastern Partnership Index. 2019. URL: https://emerging-europe.com/(дата звернення 25.04.2021).

Maksymenko I., Kuzmin D. Ukraine - European Union Relations through the Prism of Strategic Culture. Strategic Culture and Foreign Policy of Ukraine / Koval I., Brusylovska O., Dubovyk V. (eds.). Odesa: Odesa Mechnikov National University, 2017. P. 54-75.

Nye J. Jr. Soft Power: The Means to Success in World Politics. New York: Public Affairs, 2004. $191 \mathrm{p}$.

Pipchenko N. Digital Diplomacy: How International Actors Transform their Foreign Policy Activity. UA: Ukraine Analytica. 2020. Vol. 2, No. 20. P. 19-25. URL: https://ukraineanalytica.org/wp-content/uploads/Pipchenko.pdf (дата звернення 25.04.2021).

Questions and Answers about the East StratCom Task Force. 2018. URL: https://eeas.europa. eu/headquarters/headquarters-homepage/2116/node/2116_en) (дата звернення 20.04.2021).

The EU «Horizon Europe» program has started. Researchers prepare. Kiev Polytechnic. 2021. Vol. 5. URL: https://kpi.ua/en/2021-kp5-icd. (дата звернення 18.04.2021).

Trobbiani R., Pavyn-Guinea A. Culture in EU External Relations: Strategic Reflections and Future Scenarios. 2019. URL: https://cris.unu.edu/sites/cris.unu.edu/files/EL-CSID $\% 20$ Policy \% 20Paper \% 202019-16.pdf (дата звернення 10.04.2021).

What is Soft Power? USC Center on Public Diplomacy. 2019. URL: https://softpower30.com/ what-is-soft-power/(дата звернення 18.04.2021).

Стаття надійшла до редакиї̈ 01.06.2021

Брусиловська О. І., Хакімова В. Т. кафедра міжнародних відносин ОНУ імені I. І. Мечникова к. 32 , Французький бул. 24/26, м. Одеса, 65058, Україна

\section{ОСОБЛИВОСТІ СТРАТЕГІЇ М'ЯКОЇ СИЛИ ЄС ЩОДО УКРАЇНИ}

\section{Резюме}

Проголошуючи новий світовий порядок, лідери західних держав передбачали розширення миру та стабільності, допомагаючи європеїзації та інтеграції Центральної та Східної Європи. Однак ситуація з Україною складніша. Метою статті є розкриття особливостей м'якої сили ЄС щодо України. Методологія заснована на 
дослідженнях Джозефа Ная та Центру громадської дипломатії США. Обидва були адаптовані та впроваджені згідно з цілями поточного дослідження. Найважливішими питаннями стали такі: Що робить ЄС привабливим за кордоном? Наскільки ЄC покладається на свою привабливість у відносинах з Україною? Що заважає ЄC ефективніше проводити свою політику м'якої сили щодо України? Європейський Союз є одним з найбільш незвичних суб'єктів світової політики, оскільки використовує переважно інструменти м'якої сили для захисту своїх цінностей за кордоном. Дж. С. Най визначив м'яку силу як «здатність формувати уподобання інших». Ключовим аспектом м'якої сили є привабливість країни. Незважаючи на численні критичні зауваження щодо концепції, навіть такі реалісти, як Карр та Моргентау, визнавали, що влада була не лише військовою та економічною. Для того щоб впливати на поведінку інших, важливими елементами влади є участь, вплив на громадську думку в інших країнах, можливість бути прийнятим як фігура з авторитетом, формувати соціальні категорії суб’єктів світової політики. Центр цифрової дипломатії Центру державної дипломатії США у Портленді розробив оригінальну модель для вивчення м'якої сили держав, яку корисно враховувати при вивченні сили ЄC. В результаті цієї роботи з'ясувалося, що вплив СС на Україну і зокрема на вирішення поточного конфлікту з РФ був незначним. Це парадокс, якщо розглянути окремі характеристики обох акторів. ЄС все ще програє Росії в області цифрової дипломатії. Однак за привабливістю культурних досягнень сила ЄС приблизно така ж, як і у Росії. Сила дипломатичної мережі, її внесок у глобальну взаємодію в разі ЄC відносно вище, ніж у Росії. Нарешті сила ЄС набагато вище, ніж у Росії в сфері привабливості економічної моделі, дружелюбності до бізнесу і спроможності до інновацій; за рівнем людського капіталу, вкладу в стипендії і привабливість для іноземних студентів; у контексті прихильності свободі, правам людини і демократії, а також якості політичних інститутів. Надалі слід провести дослідження цього феномена і з'ясувати, що впливає на невміння ЄС ефективно використовувати свої переваги м'якої сили.

Ключові слова: Європейський Союз, Україна, м'яка сила, цифрова дипломатія, велика стратегія, Угода про асоціацію.

Брусиловская О. И., Хакимова В. Т.

кафедра международных отношений ОНУ имени И. И. Мечникова, к. 32, Французский бул. 24/26, г. Одесса, 65058, Украина

\section{ОСОБЕННОСТИ СТРАТЕГИИ МЯГКОЙ СИЛЫ ЕС В ОТНОШЕНИИ УКРАИНЫ}

Резюме

Провозгласив новый мировой порядок, лидеры западных государств обеспечили расширение мира и стабильности, способствуя европеизации и интеграции Центральной и Восточной Европы. Однако с Украиной ситуация сложнее. Целью статьи является определение особенностей стратегии мягкой силы ЕС относительно Украины. Методология основана на исследованиях Джозефа Ная и Центра общественной дипломатии США. Оба были адаптированы для целей данного исследования. Наиболее важными вопросами являются следующие: Что делает ЕС привлекательным за границей? Насколько ЕС рассчитывает на свою привлекательность в отношениях с Украиной? Что мешает ЕС эффективнее проводить свою политику мягкой силы относительно Украины? Европейский Союз является одним из самых необычных субъектов мировой политики, поскольку использует преимущественно 
инструменты мягкой силы для защиты своих ценностей за рубежом. Дж. С. Най определил мягкую силу как «способность формировать предпочтения других». Ключевым аспектом мягкой силы является привлекательность страны. Несмотря на критические замечания в адрес концепции, даже такие реалисты, как Карр и Моргентау, признавали, что власть была не только военной и экономической. Для того чтобы влиять на поведение других, важными элементами власти является участие, влияние на общественное мнение в других странах, возможность быть принятым как фигура с авторитетом, формировать социальные категории субъектов мировой политики. Центр цифровой дипломатии Центра государственной дипломатии США в Портленде разработал оригинальную модель для изучения мягкой силы государств, которую полезно учитывать при изучении силы ЕС. В результате этой работы выяснилось, что влияние ЕС на Украину и в частности на решение текущего конфликта с РФ было незначительным. Это парадокс, если рассмотреть отдельные характеристики обоих акторов. ЕС все еще проигрывает России в области цифровой дипломатии. Однако по привлекательности культурных достижений сила ЕС примерно такая же, как и у России. Сила дипломатической сети, ее вклад в глобальное взаимодействие в случае ЕС относительно выше, чем у России. Наконец сила ЕС намного выше, чем у России в сфере привлекательности экономической модели, дружелюбия к бизнесу и способности к инновациям; по уровню человеческого капитала, вкладу в стипендии и привлекательности для иностранных студентов; в контексте приверженности свободе, правам человека и демократии, а также качеству политических институтов. В дальнейшем следует провести исследование этого феномена и выяснить, что влияет на неумение ЕС эффективно использовать свои преимущества мягкой силы.

Ключевые слова: Европейский Союз, Украина, мягкая сила, цифровая дипломатия, великая стратегия, Соглашение об ассоциации. 